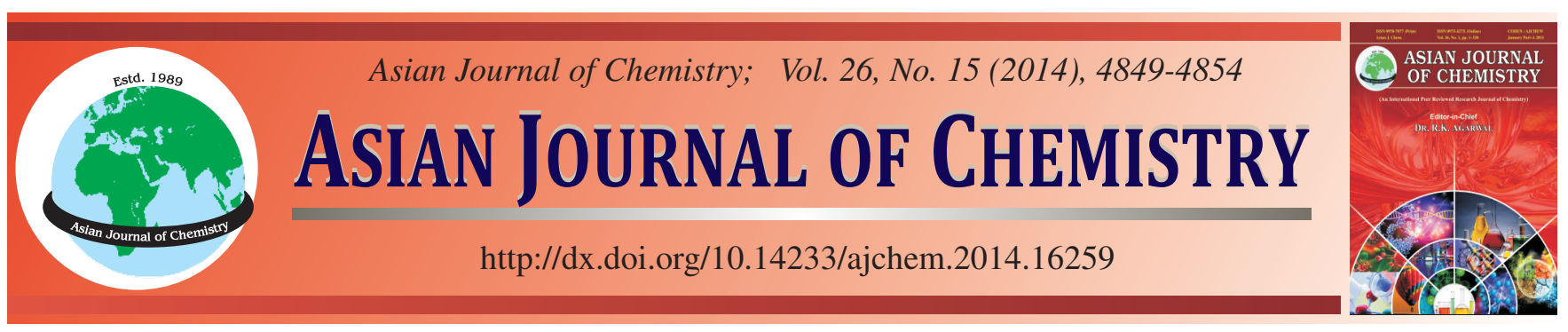

\title{
Optimization of Dispersive Liquid-Liquid Microextraction Based on Solidification of Floating Organic Drop of Endocrine Disrupting Compounds in Liquid Food Samples Using Response Surface Plot Method
}

\author{
Yu Li ${ }^{1,2, *}$ and ChEN ZHANG ${ }^{1,2}$
}

${ }^{1}$ Resources and Environmental Research Academy, North China Electric Power University, Beijing, P.R. China

${ }^{2}$ MOE Key Laboratory of Regional Energy Systems Optimization, North China Electric Power University, P.O. Box 58, Beijing 102206, P.R. China

*Corresponding author: Tel/Fax: +86 10 61773886; E-mail: liyuxx8@hotmail.com

Accepted: 19 December 2013;

Published online: 16 July 2014;

AJC-15585

\begin{abstract}
A dispersive liquid-liquid microextraction-solidification of floating organic drop (DLLME-SFO) method was developed for the endocrine disrupting compounds (estrone, estradiol, estriol, bisphenol A, diethylstilbestrol and 4-nonylphenol) extraction in food samples. The samples were analyzed by high-performance liquid chromatography with UV detection. Meanwhile, the conditions of endocrine disrupting compounds extraction were optimized by a response surface plot method. The result indicated that the optimum conditions for endocrine disrupting compounds extraction were: $100 \mu \mathrm{L}$ dodecanol, $0.6 \mathrm{~mL}$ acetonitrile, $5 \mathrm{~mL}$ sample and $0.5 \mathrm{~g} \mathrm{NaCl}$. The linear range of the method was $0.01-3 \mathrm{mg} / \mathrm{L}$ and the limits of detection were $0.41-7.50 \mu \mathrm{g} / \mathrm{L}$. In addition, spiking experiments were performed in soy milk, cow's milk and drinking water and the relative recoveries of the endocrine disrupting compounds ranged from 71.34-112.97\% with RSDs in the range of $0.11-11.18 \%$. The experimental results indicated that the method was suitable to apply in food samples.
\end{abstract}

Keywords: Central composite design, Endocrine disrupting compounds, Dispersive liquid-liquid extraction, Food samples.

\section{INTRODUCTION}

The US environmental protection agency (US-EPA) defines an endocrine disrupting compound as an exogenous agent that interferes with the synthesis, secretion, transport, binding, action, or elimination of natural hormones in the body that are responsible for the maintenance of homeostasis, reproduction, development and/or behavior ${ }^{1,2}$. Endocrine disrupting compounds are classified into two main classes i.e., steroid estrogens and endocrine-disrupting phenolic compounds, both of which are considered important in environmental studies ${ }^{3}$. Steroid estrogens, such as estrone (E1), estradiol (E2) and estriol (E3), have a high estrogenic capacity and are found in animals and plants. For example, previous studies have shown that E2, even at low concentrations (ng/L), can induce the secretion and synthesis of vitellogenin in male fish and reverse the sex of fish in a population ${ }^{4-7}$. Bisphenol A (BPA), 4-nonylphenol (4NP) and diethylstilbestrol (DES) are endocrine-disrupting phenolic compounds. Bisphenol A is a synthetic plasticizer used in polycarbonates. While bisphenol A has a lower estrogenic capacity than steroid estrogens, it has been shown to exert estrogenic activity at $\mu \mathrm{g} / \mathrm{L}$ levels in the environment ${ }^{8,9}$. 4-Nonylphenol is a degradation product of alkylphenolpoly- thoxylates (APEOs) that are mainly used as detergents and emulsifiers in industrial and commercial applications ${ }^{10}$. Previous studies have found that nonylphenol is toxic to the aquatic life, meanwhile it is able to inducing breast tumour cell proliferation ${ }^{11,12}$. Diethylstilbestrol is a synthetic estrogen that is widely used in human drugs and animal food and has been shown to be carcinogenic in embryos ${ }^{13-15}$. As endocrine disrupting compounds can interfere with both the endocrine system and normal hormonal functions in animals and humans ${ }^{16-18}$, the detection of these compounds in food and drink is important. Therefore, the development of a rapid, low toxicity and environmentally friendly method for endocrine disrupting compound determination is necessary ${ }^{19}$.

Recently, many different sample preparation techniques, including solid phase extraction (SPE) ${ }^{20}$, solid-phase microextraction $(\mathrm{SPME})^{21}$, stir bar sorptive extraction $(\mathrm{SBSE})^{22}$, hollow fiber liquid-phase microextraction (HF-LPME) ${ }^{23}$, supercritical fluid extraction ${ }^{24}$ and dispersive liquid-liquid microextraction (DLLME) ${ }^{25}$ have been developed for the extraction and pre-concentration of target analytes in aqueous samples. There are a number of disadvantages to these techniques. Solid phase extraction is time-consuming and uses hazardous solvents. Solid-phase microextraction and stir bar 
sorptive extraction do not require solvents and are quick but the coated fibers used for extraction are expensive, fragile and have short lifetimes. HF-LPME does not consume a lot of solvent but the efficiency of extraction is low and the process is time consuming. DLLME is a simple and fast technique with high recoveries that is utilized extensively for organic and inorganic extractions. Dispersive liquid-liquid microextraction based on solidification of floating organic drops (DLLME-SFO) is a combination technique that has been previously used successfully for the extraction of organochlorine pesticides from water samples ${ }^{26-28}$.

High performance liquid chromatography and gas chromatography (GC) are commonly used for the determination of endocrine disrupting compounds. Both techniques can be interfaced with mass spectrometry (MS) or tandem MS (MS-MS) detection $^{29,30}$. GC analysis usually requires sample derivatization, while HPLC analysis is rapid, highly reproducible and samples can be directly injected after sample pretreatment.

In the present study, the main parameters for DLLME-SFO extraction of endocrine disrupting compounds were optimized using both central composite design and response surface plots. The applicability of the optimized method for the analysis of liquid food samples was also evaluated.

\section{EXPERIMENTAL}

E1, E2, E3, bisphenol A, diethylstilbestrol and nonylphenol (purity $>97 \%$ ) were purchased from Sigma-Aldrich (Germany). Methanol and acetonitrile (HPLC grade) were obtained from Burdick \& Jackson (USA). $\mathrm{NaCl}$ (AR) was bought from Beijing Chemical Works (Beijing, China). Dodecanol (purity > $98 \%$ ) was acquired from Beijing Hengyezhongyuan Chemical Co. Ltd. (Beijing, China). Soy milk, cow's milk and drinking water were purchased from a market in Beijing. Soy milk and cow's milk samples were diluted in water (1: 99, v/v). Milli-Q ultrapure water (Millipore, USA) was also used.

Mixed stock solutions of endocrine disrupting compounds were prepared by dissolving the endocrine disrupting compounds in methanol at concentrations of $100 \mathrm{mg} / \mathrm{L}$ for all endocrine disrupting compounds. Working standard solutions of targets endocrine disrupting compounds were prepared by dilutions of the stock solution. Both the stock solution and working standard solutions were stored at $4{ }^{\circ} \mathrm{C}$ until use.

General procedure: A $5 \mathrm{~mL}$ aliquot of water was dispensed into a $10 \mathrm{~mL}$ screw cap glass tube with a conical bottom. A mixture of acetonitrile (dispersive solvent) and dodecanol (extraction solvent) was injected rapidly into the glass tube using a $2 \mathrm{~mL}$ glass syringe, resulting in the formation of a cloudy solution. The mixture was centrifuged for $8 \mathrm{~min}$ at $3800 \mathrm{rpm}$. The tube was then transferred into an ice bath for 8 $\mathrm{min}$. The solidified extraction solvent was transferred to a $2 \mathrm{~mL}$ vial.
Detection method: Endocrine disrupting compounds were separated and quantified using a gradient elution method using water (A) and methanol (B). The elution program used was: $0-10 \mathrm{~min}, 70 \% \mathrm{~B}$; $10-24 \mathrm{~min}, 70$ to $100 \% \mathrm{~B} ; 24-25 \mathrm{~min}$ 100 to $70 \% \mathrm{~B}$. The flow rate of mobile phase was $1 \mathrm{~mL} / \mathrm{min}$. The column temperature was $30{ }^{\circ} \mathrm{C}$. The UV detector was operated at $280 \mathrm{~nm}$.

\section{RESULTS AND DISCUSSION}

A central composite design (CCD) was employed to optimize the extraction conditions and maximize endocrine disrupting compound recovery. Four independent variables (extractant volume $\left(\mathrm{X}_{1}\right)$, dispersant volume $\left(\mathrm{X}_{2}\right)$, sample volume $\left(\mathrm{X}_{3}\right)$ and salt effect $\left(\mathrm{X}_{4}\right)$ ) were studied at five levels. The range and center point values of the four independent variables (Table-1) were based on preliminary experiments. A central composite design with seven repetitions at center point values was established with extraction recovery as the response.

Model fitting: In order to obtain high extraction recoveries for DLLME-SFO for the simultaneous determination of endocrine disrupting compounds in water samples, extraction conditions were optimized using a central composite design based on preliminary experiments. The relationship between four independent variables (extractant volume $\left(\mathrm{X}_{1}\right)$, dispersant volume $\left(\mathrm{X}_{2}\right)$, sample volume $\left(\mathrm{X}_{3}\right)$ and salt effect $\left(\mathrm{X}_{4}\right)$ ) and extraction recovery $(\mathrm{ER})$ responses for six EDCs $\left(\mathrm{Y}_{1}-\mathrm{Y}_{6}\right)$ were investigated.

Table-2 shows the parameters of the 31 experiments and the ER responses for the six endocrine disrupting compounds (E1, E2, E3, bisphenol A, diethylstilbestrol and nonylphenol). An analysis of variance (ANOVA) was performed to determine the significance of each of the factors. Based on the ANOVA results, a regression model revealed the main factors and the interactions between factors for each analyte. The models for the extraction recovery of E1, E2, E3, bisphenol A, diethylstilbestrol and nonylphenol were significant at the $95 \%$ confidence level $(\mathrm{P}<0.05)$. In the regression models, $\mathrm{Y}_{1}$ to $\mathrm{Y}_{6}$ represented the ER responses of E1, E2, E3, bisphenol A, diethylstilbestrol and nonylphenol respectively. The regression models are described by the following equations (in uncoded values):

$$
\begin{aligned}
& \mathrm{E} 3: \mathrm{Y}_{1}=-3.86782+0.329167 * \mathrm{X}_{1}+5.727769 * \mathrm{X}_{4} \\
& -0.021031 * X_{1} * X_{4}-7.25937 * X_{2} * X_{2}+0.973675 * X_{2} * X_{3} \\
& -0.074012 * \mathrm{X}_{3} * \mathrm{X}_{4}-0.140333 * \mathrm{X}_{4} * \mathrm{X}_{4} \\
& \text { BPA: } \mathrm{Y}_{2}=66.9723+0.884167 * \mathrm{X}_{4}+0.000283 * \mathrm{X}_{1} * \mathrm{X}_{1} \\
& -10.68277 * \mathrm{X}_{2} * \mathrm{X}_{2}+0.09532 * \mathrm{X}_{3} * \mathrm{X}_{3} \\
& \text { DES: } \mathrm{Y}_{3}=106.5141-5.870021 * \mathrm{X}_{3}-0.000065 * \mathrm{X}_{1} * \mathrm{X}_{1} \\
& -82.52166 * X_{2} * X_{2}+19.56997 * X_{2} * X_{3}+0.06101 * X_{2} * X_{4} \\
& -0.81055 * X_{3} * X_{3} \\
& \mathrm{E} 2: \mathrm{Y}_{4}=-51.3723+2.522654 * \mathrm{X}_{1}-0.011928 * \mathrm{X}_{1} * \mathrm{X}_{1} \\
& -14.18529 * \mathrm{X}_{2} * \mathrm{X}_{2}+0.400959 * \mathrm{X}_{2} * \mathrm{X}_{4}-0.000801 * \mathrm{X}_{3} * \mathrm{X}_{3} \\
& \mathrm{E} 1: \mathrm{Y}_{5}=-57.8147+2.484 * \mathrm{X}_{1}-0.011506 * \mathrm{X}_{1} * \mathrm{X}_{1}
\end{aligned}
$$

TABLE-1

FACTORS AND LEVELS SELECTED IN DLLME-SFO PROCEDURES BASED ON THE CENTRAL COMPOSITE DESIGN

\begin{tabular}{lccccc}
\hline \multicolumn{1}{c}{ Factors } & -2 & -1 & 0 & +1 & +2 \\
\hline Extractant volumes $\mathrm{X}_{1}(\mu \mathrm{L})$ & 60 & 80 & 100 & 120 & 140 \\
Dispersant volumes $\mathrm{X}_{2}(\mathrm{~mL})$ & 0.2 & 0.4 & 0.6 & 0.8 & 7.0 \\
Sample volumes $\mathrm{X}_{3}(\mathrm{~mL})$ & 1 & 3 & 5 & 10 & 9 \\
Salt effect $\mathrm{X}_{4}(\%)$ & 0 & 5 & 10 & 15 & 20 \\
\hline
\end{tabular}


UNCODED VARIABLE VALUES OF THE CENTRAL COMPOSITE DESIGN AND THE RESPONSES

\begin{tabular}{|c|c|c|c|c|c|c|c|c|c|c|}
\hline No. & $\begin{array}{c}\text { Extractant } \\
\text { volume } \\
\left(\mathrm{X}_{1}, \mu \mathrm{L}\right)\end{array}$ & $\begin{array}{c}\text { Dispersant } \\
\text { volumes } \\
\left(\mathrm{X}_{2}, \mathrm{~mL}\right)\end{array}$ & $\begin{array}{c}\text { Sample } \\
\text { volumes } \\
\left(\mathrm{X}_{3}, \mathrm{~mL}\right)\end{array}$ & $\begin{array}{l}\text { Salt effect } \\
\left(\mathrm{X}_{4}, \%\right)\end{array}$ & $\mathrm{E}_{3}\left(\mathrm{Y}_{1}, \%\right)$ & $\begin{array}{c}\text { BPA } \\
\left(\mathrm{Y}_{2}, \%\right)\end{array}$ & $\begin{array}{c}\text { DES } \\
\left(\mathrm{Y}_{3}, \%\right)\end{array}$ & $\begin{array}{c}\mathrm{E}_{2} \\
\left(\mathrm{Y}_{4}, \%\right)\end{array}$ & $\begin{array}{c}\mathrm{E}_{1} \\
\left(\mathrm{Y}_{5}, \%\right)\end{array}$ & $\begin{array}{c}\mathrm{NP} \\
\left(\mathrm{Y}_{6}, \%\right)\end{array}$ \\
\hline 1 & 80 & 0.4 & 3 & 5 & 39.77 & 58.53 & 75.74 & 61.44 & 55.44 & 98.46 \\
\hline 3 & 80 & 0.4 & 7 & 5 & 35.77 & 61.73 & 71.24 & 66.54 & 62.41 & 50.18 \\
\hline 4 & 80 & 0.4 & 7 & 15 & 47.27 & 74.55 & 57.00 & 61.87 & 58.37 & 45.50 \\
\hline 5 & 80 & 0.8 & 3 & 5 & 38.24 & 59.55 & 76.31 & 63.76 & 56.29 & 67.48 \\
\hline 7 & 80 & 0.8 & 7 & 5 & 31.77 & 55.09 & 73.52 & 64.03 & 57.36 & 41.74 \\
\hline 8 & 80 & 0.8 & 7 & 15 & 49.96 & 87.07 & 78.93 & 79.90 & 72.76 & 56.42 \\
\hline 9 & 120 & 0.4 & 3 & 5 & 51.30 & 77.84 & 94.83 & 86.41 & 79.74 & 81.64 \\
\hline 10 & 120 & 0.4 & 3 & 15 & 45.11 & 71.83 & 82.49 & 80.16 & 66.37 & 93.63 \\
\hline 11 & 120 & 0.4 & 7 & 5 & 38.81 & 68.53 & 74.56 & 84.18 & 75.55 & 57.32 \\
\hline 12 & 120 & 0.4 & 7 & 15 & 38.65 & 66.85 & 40.82 & 56.05 & 59.09 & 17.20 \\
\hline 13 & 120 & 0.8 & 3 & 5 & 42.12 & 57.29 & 74.64 & 63.56 & 62.37 & 21.94 \\
\hline 15 & 120 & 0.8 & 7 & 5 & 43.34 & 70.20 & 75.30 & 70.58 & 68.86 & 24.27 \\
\hline 16 & 120 & 0.8 & 7 & 15 & 50.84 & 85.28 & 78.36 & 75.78 & 73.40 & 26.30 \\
\hline 17 & 60 & 0.6 & 5 & 10 & 38.61 & 67.29 & 64.54 & 64.09 & 62.46 & 28.45 \\
\hline 18 & 140 & 0.6 & 5 & 10 & 53.94 & 75.20 & 66.91 & 69.00 & 69.83 & 15.57 \\
\hline 19 & 100 & 0.2 & 5 & 10 & 38.09 & 72.85 & 75.94 & 74.39 & 72.08 & 32.00 \\
\hline 20 & 100 & 1.0 & 5 & 10 & 36.34 & 54.33 & 62.59 & 57.23 & 53.81 & 34.78 \\
\hline 21 & 100 & 0.6 & 1 & 10 & 59.17 & 60.75 & 85.06 & 70.69 & 69.65 & 31.14 \\
\hline 22 & 100 & 0.6 & 9 & 10 & 51.43 & 87.91 & 78.19 & 80.84 & 78.68 & 45.53 \\
\hline 23 & 100 & 0.6 & 5 & 0 & 67.85 & 97.95 & 92.18 & 91.13 & 87.41 & 89.28 \\
\hline 24 & 100 & 0.6 & 5 & 20 & 65.23 & 101.66 & 96.60 & 86.52 & 91.34 & 96.16 \\
\hline 25 & 100 & 0.6 & 5 & 10 & 61.29 & 90.34 & 102.39 & 84.85 & 81.91 & 89.59 \\
\hline 26 & 100 & 0.6 & 5 & 10 & 63.04 & 96.10 & 101.71 & 85.27 & 79.16 & 91.20 \\
\hline 27 & 100 & 0.6 & 5 & 10 & 64.79 & 94.66 & 97.96 & 86.94 & 83.08 & 89.89 \\
\hline 28 & 100 & 0.6 & 5 & 10 & 69.16 & 94.45 & 90.31 & 81.50 & 78.48 & 91.20 \\
\hline 29 & 100 & 0.6 & 5 & 10 & 62.60 & 91.57 & 96.26 & 86.10 & 83.87 & 89.89 \\
\hline
\end{tabular}

TABLE-3

STATISTICAL SIGNIFICANT AND PARAMETERS OF THE REGRESSION MODEL FOR SIX ENDOCRINE DISRUPTING COMPOUNDS

\begin{tabular}{ccccccc}
\hline \multirow{2}{*}{ Variable } & \multicolumn{5}{c}{ Extraction recovery } \\
\cline { 2 - 7 } & E3 & BPA & DES & E2 & E1 & NP \\
\hline $\mathrm{R}^{2}$ & 0.8742 & 0.8517 & 0.8631 & 0.8390 & 0.7947 & 0.8379 \\
$\mathrm{R}^{2}$ adjusted & 0.7641 & 0.7220 & 0.7632 & 0.6980 & 0.6151 & 0.6961 \\
RMSE $^{\mathrm{a}}$ & 3.4675 & 7.6969 & 7.1442 & 5.8017 & 6.7404 & 15.9294 \\
$\mathrm{CV}^{\mathrm{b}}(\%)$ & 7.7178 & 9.9656 & 8.8715 & 7.7613 & 9.5276 & 27.2081 \\
Prob $>\mathrm{F}$ & $<0.0001$ & 0.0003 & 0.0002 & 0.0005 & 0.0029 & 0.0006 \\
\hline${ }^{a}$ RMSE, the root mean square error, ${ }^{\mathrm{b}} \mathrm{CV}$, coefficient of variation
\end{tabular}

$-14.90015 * \mathrm{X}_{2} * \mathrm{X}_{2}+0.559176 * \mathrm{X}_{2} * \mathrm{X}_{4}+0.044712 * \mathrm{X}_{3} * \mathrm{X}_{3}$ $\mathrm{NP}: \mathrm{Y}_{6}=66.05968+160.2463 * \mathrm{X}_{2}-0.001818 * \mathrm{X}_{1} * \mathrm{X}_{1}$ - 299.3665* $\mathrm{X}_{2} * \mathrm{X}_{2}+31.39328 * \mathrm{X}_{2} * \mathrm{X}_{3}-2.20847 * \mathrm{X}_{3} * \mathrm{X}_{3}$

The statistical significance of an effect at the $95 \%$ confidence level for each regression model was determined using an F-test. $\mathrm{R}^{2}$ and adjusted $\mathrm{R}^{2}$ were also calculated (Table-3). As shown in Table-3, the $\mathrm{R}^{2}$ values of the models were 0.7947 - 0.9574, indicating that the model can explain 79.47-95.74\% of the ER variability. Adjusted $\mathrm{R}^{2}$ values were 0.6151- 0.9501 . The root mean square error (RMSE) and coefficient of variation $(\mathrm{CV})$ reflect the extent of discrete and variety of independent variables, respectively.
It can be inferred from the models generated whether the $\mathrm{X}_{1}$ to $\mathrm{X}_{4}$ coefficients positively or negatively influenced the extraction responses. On the basis of the regression model, $\mathrm{X}_{1}$ and the interaction of $\mathrm{X}_{2}$ and $\mathrm{X}_{3}$ (or $\mathrm{X}_{2}$ and $\mathrm{X}_{4}$ ) all positively affected the responses of six endocrine disrupting compounds, while other interactions of $X_{1}-X_{4}$ had negative effects. In the model for $\mathrm{E} 3, \mathrm{X}_{1}$ and $\mathrm{X}_{4}$ were the main parameters with significant influence on the extraction responses. $\mathrm{X}_{1}$ was the significant factor for E2 and E1 while the significant main factors for bisphenol A, diethylstilbestrol and nonylphenol were $\mathrm{X}_{4}$, $\mathrm{X}_{3}$ and $\mathrm{X}_{2}$, respectively. 

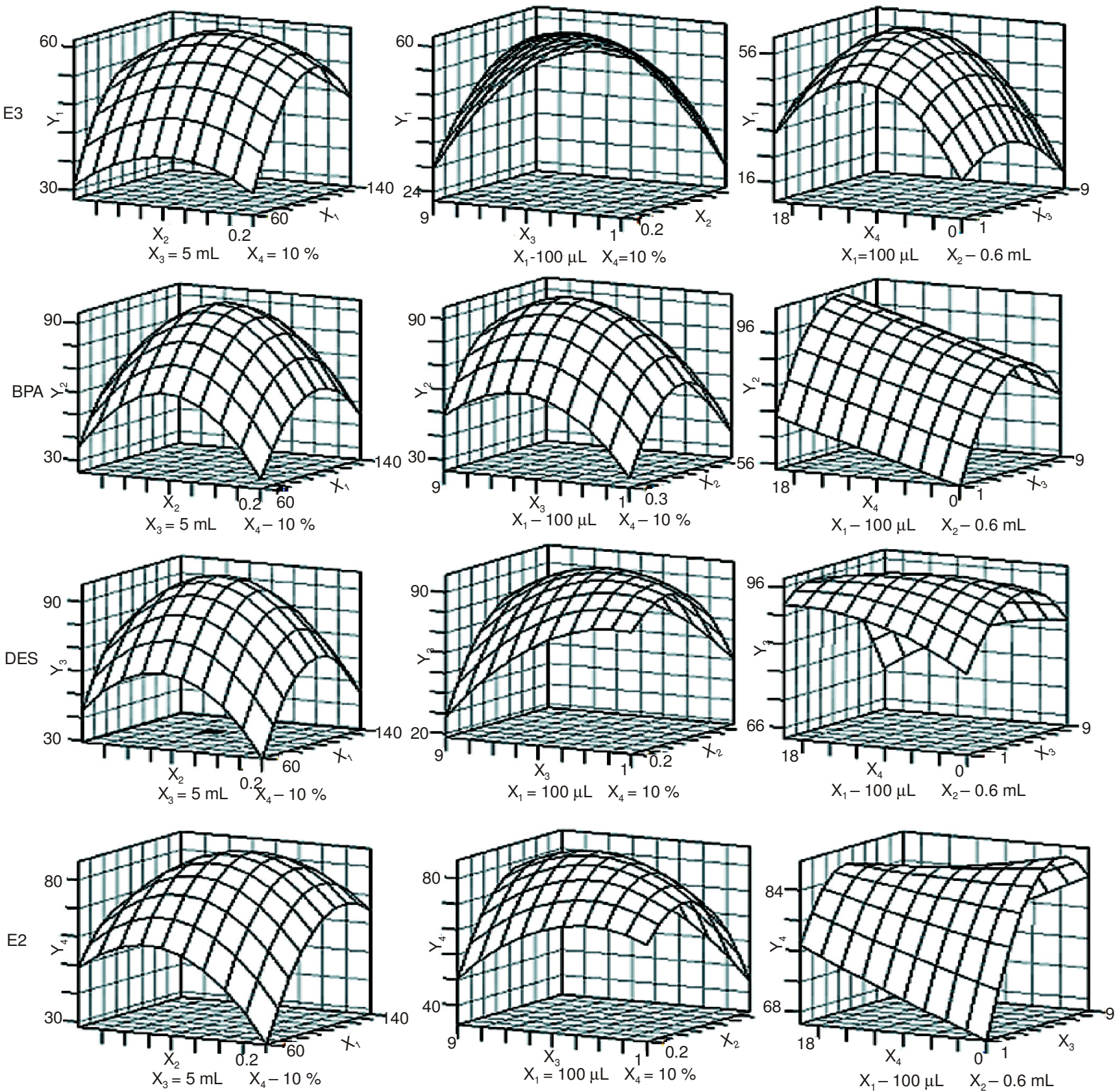

Fig. 1. Response surface plots for the recovery yield of six endocrine disrupting compounds, as a function of extractant volumes and dispersant volumes (left), dispersant volumes and sample volumes (middle), sample volumes and salt effect (right)

Optimization by central composite design: In order to obtain the optimal extraction recovery, the established regression models were used to predict and optimize all of the independent variances. 3-D response surface plots were generated and indicate the relationship between independent variances and the predicted conditions at optimum points (Fig. 1).

As shown in Fig. 1, the curvature of the response surface from the interaction of factors indicates the significance of the interaction between factors. The higher rate of curvature of the response factors, the more significant the interactions between the factors. In general, $X_{1}$ and $X_{2}, X_{2}$ and $X_{3}$ and $X_{3}$ and $\mathrm{X}_{4}$ interacted to influence the extraction recoveries. The interactions of $X_{1}$ and $X_{2}$ and $X_{2}$ and $X_{3}$ had positive effects on the extraction recoveries, while the interaction of $X_{3}$ and $\mathrm{X}_{4}$ had negative effects, in accordance with the model. In addition, the left side of Fig. 1 indicate that the endocrine disrupting compound extraction recoveries should reach the optimum value when $\mathrm{X}_{1}$ (extractant volume) and $\mathrm{X}_{2}$ (dispersant volume) are at the center points. The middle of Fig. 1 also show that the optimum extraction recoveries were obtained as $\mathrm{X}_{2}$ (dispersant volume) and $\mathrm{X}_{3}$ (sample volume) were both at the center points. The right side of Fig. 1 indicate that the extraction recoveries achieved relative optimum values when $X_{3}$ (sample volume) and $\mathrm{X}_{4}$ (salt effect) were at the center points. The optimal conditions for the simultaneous extraction of the 6 endocrine disrupting compounds were: $100 \mu \mathrm{L}$ extractant volume, 0.6 $\mathrm{mL}$ dispersant volume, $5 \mathrm{~mL}$ sample volume and $0.5 \mathrm{~g} \mathrm{NaCl}$. Nine replicate experiments were performed at the optimum conditions and the relative standard deviation of the prediction and experimental value were $0-4.80 \%$. 


\begin{tabular}{cccc}
\hline & \multicolumn{2}{c}{ TABLE-4 } \\
& $\begin{array}{c}\text { QUANTITATIVE RESULTS OF DLLME-SFO FOR DETERMINATION OF } \\
\text { ENDOCRINE DISRUPTING COMPOUNDS IN WATER SAMPLE }\end{array}$ \\
\hline Organics & LR $^{\mathrm{b}}(\mathrm{mg} / \mathrm{L})$ & $\mathrm{r}^{\mathrm{c}}$ & $\mathrm{LD}^{\mathrm{d}}(\mu \mathrm{g} / \mathrm{L})$ \\
\hline E3 & $0.01-3.00$ & 0.9999 & 1.38 \\
BPA & $0.01-3.00$ & 0.9999 & 0.41 \\
EES & $0.01-3.00$ & 0.9996 & 3.03 \\
E1 & $0.01-3.00$ & 0.9999 & 7.14 \\
NP & $0.01-3.00$ & 0.9999 & 1.36 \\
\hline
\end{tabular}

${ }^{a}$ Extraction conditions: extractant (dodecanol) volume, $100 \mu \mathrm{L}$; dispersant (acetonitrile) volume, $0.6 \mathrm{~mL}$; water sample, $5 \mathrm{~mL}$; salt effect (NaCl), 10 $\%$; solidified phase volume, $100 \pm 0.4 \mu \mathrm{L}$; solidified temperature, $-20{ }^{\circ} \mathrm{C}$; solidified time, $8 \mathrm{~min}$, ${ }^{\mathrm{b}} \mathrm{LR}$, linear range, ${ }^{\mathrm{c}} \mathrm{r}^{2}$, correlation coefficient,

${ }^{\mathrm{d}} \mathrm{LOD}$, limit of detection for $\mathrm{S} / \mathrm{N}=3$, ${ }^{\mathrm{L}} \mathrm{LOQ}$, limit of quantitation for $\mathrm{S} / \mathrm{N}=10$

\begin{tabular}{|c|c|c|c|c|c|c|c|c|c|}
\hline \multirow[b]{3}{*}{ Compounds } & \multicolumn{8}{|c|}{$\begin{array}{l}\text { TABLE-5 } \\
\text { RINE DISRUPTING C }\end{array}$} & \\
\hline & \multicolumn{3}{|c|}{ Soy milk } & \multicolumn{3}{|c|}{ Cow's milk } & \multicolumn{3}{|c|}{ Drink water } \\
\hline & $\begin{array}{c}\text { Spiked } \\
\text { level } \\
(\mu \mathrm{g} / \mathrm{L})\end{array}$ & $\begin{array}{c}\text { Found (RSD } \\
\left.{ }^{\mathrm{a}}, \mathrm{n}=3\right) \\
(\mu \mathrm{g} / \mathrm{L})\end{array}$ & $\begin{array}{c}\text { Relative } \\
\text { recovery (\%) }\end{array}$ & $\begin{array}{c}\text { Spiked } \\
\text { level } \\
(\mu \mathrm{g} / \mathrm{L})\end{array}$ & $\begin{array}{c}\text { Found (RSD }{ }^{a} \text {, } \\
n=3)(\mu \mathrm{g} / \mathrm{L})\end{array}$ & $\begin{array}{c}\text { Relative } \\
\text { recovery } \\
(\%)\end{array}$ & $\begin{array}{c}\text { Spiked } \\
\text { level } \\
(\mu \mathrm{g} / \mathrm{L})\end{array}$ & $\begin{array}{c}\text { Found } \\
\left(\text { RSD }^{\mathrm{a}},\right. \\
\mathrm{n}=3)(\mu \mathrm{g} / \mathrm{L})\end{array}$ & $\begin{array}{l}\text { Relative } \\
\text { recovery } \\
(\%)\end{array}$ \\
\hline \multirow[t]{2}{*}{ E3 } & 50 & $54.9(2.84)$ & 109.80 & 50 & $42.2(3.45)$ & 84.41 & 50 & $56.5(5.15)$ & 112.97 \\
\hline & 500 & $356.7(0.95)$ & 71.34 & 500 & $480.2(4.76)$ & 96.03 & 500 & $517.9(0.80)$ & 103.58 \\
\hline \multirow[t]{2}{*}{ BPA } & 50 & $43.5(2.46)$ & 87.06 & 50 & $42.5(3.26)$ & 85.00 & 50 & $39.8(2.94)$ & 79.57 \\
\hline & 500 & $477.0(3.25)$ & 95.39 & 500 & $493.0(1.84)$ & 98.59 & 500 & $520.3(1.78)$ & 104.06 \\
\hline \multirow[t]{2}{*}{ DES } & 50 & $39.6(0.90)$ & 79.17 & 50 & $49.5(3.89)$ & 99.08 & 50 & $55.7(1.68)$ & 111.37 \\
\hline & 500 & $353.3(3.27)$ & 70.65 & 500 & $392.4(0.57)$ & 78.47 & 500 & $529.6(5.59)$ & 105.91 \\
\hline \multirow[t]{2}{*}{ E2 } & 50 & $44.6(11.18)$ & 89.15 & 50 & $44.7(10.04)$ & 89.49 & 50 & $41.5(0.64)$ & 82.98 \\
\hline & 500 & $389.7(10.70)$ & 77.94 & 500 & $405.8(1.60)$ & 81.16 & 500 & $455.4(1.16)$ & 91.08 \\
\hline \multirow[t]{2}{*}{ E1 } & 50 & $35.8(1.46)$ & 71.61 & 50 & $45.3(1.20)$ & 90.64 & 50 & $41.6(1.50)$ & 83.27 \\
\hline & 500 & $501.0(4.82)$ & 100.19 & 500 & $450.0(3.00)$ & 90.01 & 500 & $466.3(0.11)$ & 93.25 \\
\hline \multirow[t]{2}{*}{ NP } & 50 & $40.0(1.15)$ & 80.07 & 50 & $48.4(4.67)$ & 96.84 & 50 & $51.6(1.12)$ & 103.28 \\
\hline & 500 & $397.7(2.70)$ & 79.53 & 500 & $391.1(1.10)$ & 78.22 & 500 & $426.8(1.83)$ & 85.36 \\
\hline
\end{tabular}

Conditions: $100 \mu \mathrm{L}$ of extractant volume, $0.6 \mathrm{~mL}$ of dispersant, $5 \mathrm{~mL}$ of sample volumes, and $0.5 \mathrm{~g}$ of NaCl ${ }^{\mathrm{a}} \mathrm{RSD}$ : relative standard deviation

Analytical performance: Calibration curves (Table-4) were obtained under optimised conditions. The linear range was three orders of magnitude and the limit of detection was at the $\mu \mathrm{g} / \mathrm{L}$ level for all endocrine disrupting compounds.

Analysis of real samples: The developed method was applied to liquid samples (soy milk, cow's milk and drinking water) spiked with target endocrine disrupting compounds to mimic typical samples. Each liquid sample was spiked with two different concentrations of target endocrine disrupting compounds and three replicates were performed at each level (Table-5). The relative standard deviation (RSD) was 0.80$11.18 \%$, indicating that the proposed method is appropriate for the extraction of the six endocrine disrupting compounds from real food samples.

In order to investigate possible matrix effects, the proposed method was used to determine endocrine disrupting compounds in three different food samples. The samples were analyzed by HPLC-UV after DLLME-SFO. Fig. 2 shows the chromatograms obtained for soy milk and drinking water at $50 \mu \mathrm{g} / \mathrm{L}$ and $500 \mu \mathrm{g} / \mathrm{L}$ for each endocrine disrupting compound. These results demonstrate that the matrices of the analyzed real water samples have little effect on the DLLME-SFO/HPLC determination of endocrine disrupting compounds. Therefore, the established DLLME-SFO method was successfully applied to the analysis of estrone, estradiol, estriol, bisphenol A, diethylstilbestrol and 4-nonylphenol in soy milk, cow's milk and drinking water.

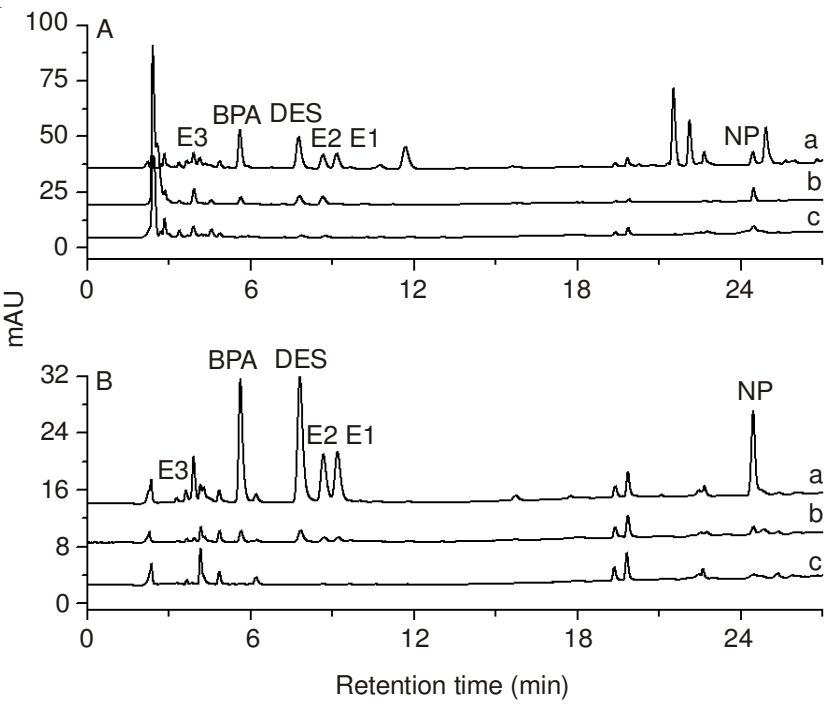

Fig. 2. Typical chromatograms of (A) Soy milk sample and (B) drinking water samples spiked with 0 (c), $0.05 \mathrm{mg} / \mathrm{L}$ (b) and $0.5 \mathrm{mg} / \mathrm{L} \mathrm{(a)} \mathrm{for}$ E3, bisphenol A, DES, E2, E1, and nonylphenol, respectively

\section{Conclusion}

A central composite design was employed for optimizing the extraction and analysis of endocrine disrupting compounds including E1, E2, E3, bisphenol A, diethylstilbestrol and 4-nonylphenol in food samples. Target endocrine disrupting compounds at the $\mu \mathrm{g} / \mathrm{L}$ level of could be successfully pre- 
concentrated by DLLME-SFO and analyzed by HPLC. In addition, the results demonstrated that the method could be utilized to analyze endocrine disrupting compounds in food samples. Furthermore, the DLLME-SFO method is rapid, easy to use and has low organic solvent consumption.

\section{ACKNOWLEDGEMENTS}

Financial support was provided by the Ministry of Science and Technology China ('973' Project No. 2004CB3418501).

\section{REFERENCES}

1. United States Environmental Protection Agency (USEPA), Washington, DC: Office of Research and Development EPA/630/R-96/012 (1997).

2. H.S. Chang, K.H. Choo, B. Lee and S.J. Choi, J. Hazard. Mater., 172, 1 (2009).

3. R. Liu, L. Zhou and A. Wilding, J. Chromatogr. A, 1022, 179 (2004).

4. C.E. Purdom, P.A. Hardiman, V.V.J. Bye, N.C. Eno, C.R. Tyler and J.P. Sumpter, Chem. Ecol., 8, 275 (1994).

5. K.A. Kidd, P.J. Blanchfield, K.H. Mills, V.P. Palace, R.E. Evans, J.M Lazorchak and R.W. Flick, Proc. Natl. Acad. Sci. USA, 104, 8897 (2007)

6. G. Li Puma, V. Puddu, H.K. Tsang, A. Gora and B. Toepfer, Appl. Catal. B, 99, 388 (2010).

7. A.B. Edelman, G. Cherala, M.Y. Munar, B. DuBois, M. McInnis, F.Z. Stanczyk and J.T. Jensen, Contraception, 87, 220 (2013).

8. Y. Toyama and S. Yuasa, Reprod. Toxicol., 19, 181 (2004).

9. X.L. Cao, G. Dufresne, S. Belisle, G. Clement, M. Falicki, F. Beraldin and A. Rulibikiye, J. Agric. Food Chem., 56, 7919 (2008).

10. M. Kawaguchi, K. Inoue, M. Yoshimura, R. Ito, N. Sakui and H. Nakazawa, Anal. Chim. Acta, 505, 217 (2004).
11. J.J. Scott-Fordsmand and P.H. Krogh, Ecotoxicol. Environ. Saf., 58, 294 (2004).

12. A.M. Soto, H. Justicia, J.W. Wray and C. Sonnenschein, Environ. Health Perspect., 92, 167 (1991).

13. A.J.J.M. Vingerhoets, J. Assies, K. Goodkin, G.L. Van Heck and M.H. Bekker, Eur. J. Obstet. Gyn. R. B., 77, 205 (1998).

14. M.L. Stefanick, Am. J. Med., 118, 64 (2005).

15. Y. Yin, C. Lin and L. Ma, Mol. Endocrinol., 20, 1535 (2005).

16. H. Nakazawa, A. Yamaguchi, K. Inoue, T. Yamazaki, K. Kato, Y. Yoshimura and T. Makino, Food Chem. Toxicol., 40, 1827 (2002).

17. J. Antignac, R. Cariou, B.L. Bizec and F. André, Food Chem., 87, 275 (2004).

18. J. Muncke, Sci. Total Environ., 407, 4549 (2009).

19. C. Almeida, J.O. Fernandes and S.C. Cunha, Food Contr., 25, 380 (2012).

20. T. Saitoh, S. Suzuki and M. Hiraide, J. Chromatogr. A, 1097, 179 (2005).

21. N. Campillo, R. Peñalver and M. Hernández-Córdoba, Talanta, 80, 1856 (2010).

22. E.D. Guerrero, R. Castro Mejías, R.N. Marín and C.G. Barroso, J. Chromatogr. A, 1165, 144 (2007).

23. J. Lee, H.K. Lee, K.E. Rasmussen and S. Pedersen-Bjergaard, Anal. Chim. Acta, 624, 253 (2008).

24. N. Hasan and B. Farouk, J. Supercrit. Fluids, 80, 60 (2013).

25. M. Rezaee, Y. Yamini and M. Faraji, J. Chromatogr. A, 1217, 2342 (2010).

26. M. Leong and D. Huang, J. Chromatogr. A, 1216, 7645 (2009).

27. M.I. Leong and S.D. Huang, J. Chromatogr. A, 1211, 8 (2008).

28. M.I. Leong, C.C. Chang, M.R. Fuh and S.D. Huang, J. Chromatogr. A, 1217, 5455 (2010).

29. G. Pojana, A. Gomiero, N. Jonkers and A. Marcomini, Environ. Int., 33, 929 (2007).

30. Y. Nie, Z. Qiang, H. Zhang and C. Adams, J. Chromatogr. A, 1216, 7071 (2009). 